\title{
The Rearing of Microplitis manilae (Hymenoptera: Braconidae) on Spodoptera litura Fabricius (Lepidoptera: Noctuidae) Feed Different Diets
}

\author{
Adha $\operatorname{Sari}^{1 *}$ \\ ${ }^{1}$ IPB University, Plant Protection Departmen, Agricultural Faculty, Bogor, West Java 16680, Indonesia \\ *Corresponding author. Email: adhass2000@yahoo.com
}

\begin{abstract}
A good rearing method is one of the keys in successful biological control practices. This also applied on biological control of Spodoptera litura Fabricius (Lepidoptera: Noctuidae). The objective of this study is to observe the development of Microplitis (Snellanius) manilae (Hymenoptera: Braconidae) on S. litura which cultured in the natural diet (host plants) and the artificial diet. This study was conducted with two treatments which were larvae of $S$. litura fed with natural diet and artificial diet. Each treatment has 10 individuals as replicates. Each larva was placed in a different petri dish along with the adult of $M$. manilae. The larvae were exposed to adult parasitoids of $M$. manilae for $24 \mathrm{hr}$. Then, the larvae were reared until the parasitoid emerged. The results showed that the highest number of parasitization was found in the hosts which were fed on an artificial diet. Whereas, the highest number of parasitoids emerged were found from the hosts which provided with a natural diet. On both diets, more female parasitoids emerged than males. The difference in nutrient content given to host larvae plays a major role in affecting the number of hosts parasitization, the number of emerged parasitoids and the sex ratio of parasitoids.
\end{abstract}

Keywords: parasitoids, artificial diet, rearing, Microplitis manilae

\section{INTRODUCTION}

Spodoptera litura Fabricius is a polyphagous pest, often found attacking various types of plants, including cultivated plants [1-3]. These insect pests are known spread throughout the subtropics to the tropics [4, 5]. Various control methods were made to reduce this pest attack, including using biological control by utilizing biological agents, namely parasitoid insects. There are several species of parasitoids known to be associated with S. litura including Microplitis sp. [5, 6], Eriborus sp. [7], and Apanteles sp. [8].

Large-scale parasitoid rearing is an important factor in biological control $[9,10]$. Many factors can influence the success of parasitoid rearing including microclimate compatibility, appropriate feed [7, 11], absence of pathogens or other natural enemies, and the absence of superparasitism [12]. The use of artificial diet is one of the most widely used methods in the rearing of host larvae, in addition to using natural food. The use of artificial diet also to facilitate the multiplication of parasitoid hosts, without having to search for natural food that sometimes has limited quantities. However, research related to information on the use of artificial diet in particular parasitoid rearing, is still limited. Information related to the role of artificial diet in parasitoid rearing in particular can be one of the basic supporting knowledge in developing standard methods of laboratory scale parasitoid rearing.
The success of laboratory scale parasitoid rearing is the main key to the success of the sustainability of field scale biological control. An effective, efficient and easy adopted mass rearing method is widely studied not only by agribusiness practitioners but also academics in educational institutions such as universities. The existence of standard methods that are efficient and easy to apply can certainly also help in the field of laboratory management, especially in the rearing of insects for educational facilities.

The objective of this study was to find a standard method of parasitoid mass rearing that is effective and easily adopted to support the education and activity in laboratory.

\subsection{Materials and Methods}

\subsubsection{Time and place}

Sampling Spodoptera litura larvae was carried out in a cultivation crop located in the Dramaga region, Bogor, West Java. Insect maintenance and identification of parasitoids were carried out at the Biological Control Laboratory, Plant Protection Department, Faculty of Agriculture, IPB University. 


\subsubsection{Rearing of Spodoptera litura}

Spodoptera litura larvae collected from the field were maintained in plastic boxes measuring $35 \times 27 \times 7 \mathrm{~cm}$. Larvae were fed with the leaves of their host plants during the maintenance period until they turn into cocoons. The number of larvae was limited to 1 larvae per box to avoid cannibalism among larvae (Figure 1). At the time of approaching the pupation, sawdust was inserted into the plastic box which functions as the media for pupation. After the pupae enters the second day, the pupae were moved into a plastic tubular cage. The emerged adults were reared in the cage and fed with water mixed with honey that dripped on cotton.

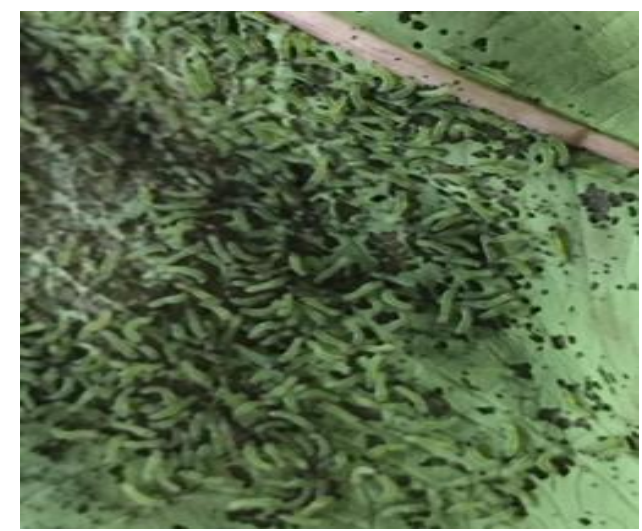

Figure 1 Spodoptera litura reared in Laboratory

\subsubsection{Rearing of Parasitoid}

Parasitoid was collected from the field by collected the parasited Spodoptera litura larvae, Microplitis manilae (Figure 2). Emerged parasitoid then reared in the cage and fed with honey that dripped on cotton. At the second day after emerged, the parasitoid was placed in a tube containing the larvae of $S$. litura for parasitized stages.

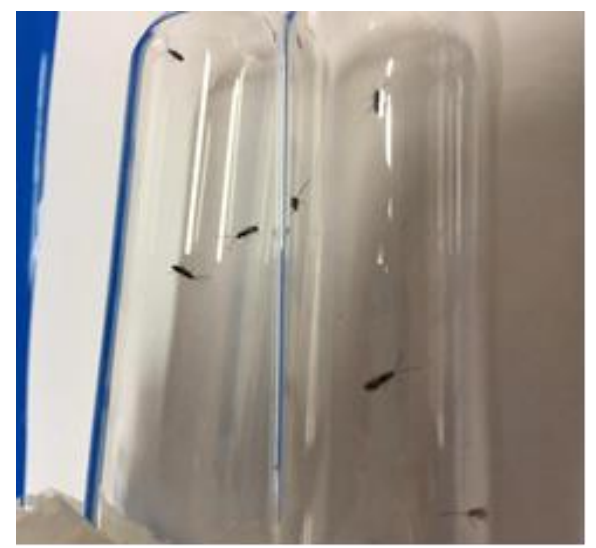

Figure 2 Parasitoid Microplitis manilae reared in Laboratorium

\subsubsection{Rearing Spodoptera litura larvae with artificial diet}

The Spodoptera litura egg batches was placed on a petri dish which had previously been filled with artificial diet. Maintenance with artificial diet was carried out until the larvae reach the $3 \mathrm{rd}$ instar. The ingredients used to make artificial diet are agar, kidney beans, wheat germ, yeast, casein, ascorbic acid, sorbic acid, methylparaben, vitamin mix, tetracycline, aquadest, honey. The steps of making artificial diet are as follows.

One hundred twenty five $\mathrm{g}$ of red beans soaked with aquadest for 1 night. The red beans that have been soaked then blended with $1000 \mathrm{~mL}$ of aquadest water. The dry ingredients such as $100 \mathrm{~g}$ wheat germ, $50 \mathrm{~g}$ casein, $62.5 \mathrm{~g}$ yeast, $66 \mathrm{~g}$ ascorbic acid, $3 \mathrm{~g}$ sorbic acid, $5 \mathrm{~g}$ methyl paraben added to red bean mixture. The mixture was heated for 2 min and set aside. Twenty four $\mathrm{g}$ of agar heated with 1000 $\mathrm{mL}$ of aquadest, then remove from heat. Heated Agar mixed with red bean mixture, $10 \mathrm{~g}$ of Vitamin mix and $0.125 \mathrm{~g}$ of tetracycline. Then poured it into a plastic box.

Artificial feed that has been cooled, then cut to a size of $1.5 \times 1.5 \mathrm{~cm}$ and placed in a small plastic container, give 1 instar larvae then closed. Artificial feed can be replaced with a new one, if the pieces of artificial feed given previously have been used up or dried out (Figure 3). Provision of artificial feed on the larvae is carried out until the larvae enter the pre-pupa period.

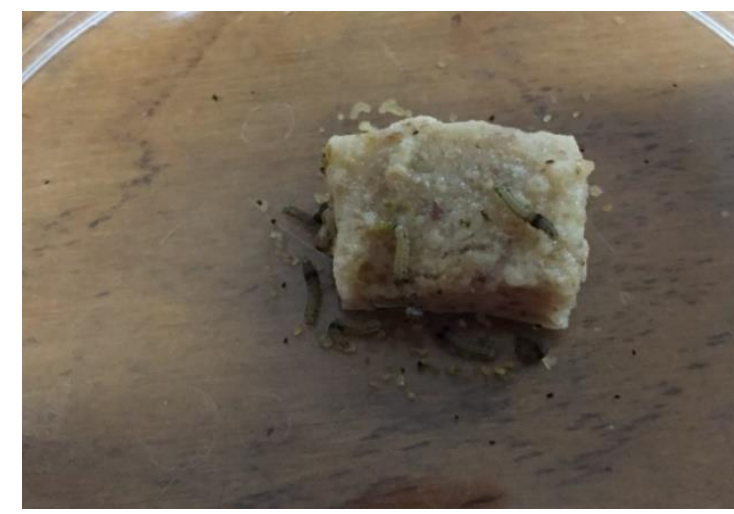

Figure 3 Artifcial diet and larvae of Spodoptera litura

\subsubsection{Parasitization of Spodoptera litura}

A total of 200 larvae consisting of 100 S. litura larvae that were reared using artificial diet and 100 larvae that were reared with natural diet of taro leaves (Colocasia esculenta) which put in 10 petri dishes. The larvae used for the parasitization stage were the second instar larvae. In each tube 10 larvae of $S$. litura and a pair of M. manila were inserted, then exposed for $24 \mathrm{hr}$ (Figure 4). The parasitized larvae were then maintained, until the parasitoids appear from the larvae. The number of individual parasitoids, as well as the sex ratio of parasitoids that appear in each larva, were then recorded for comparison. 

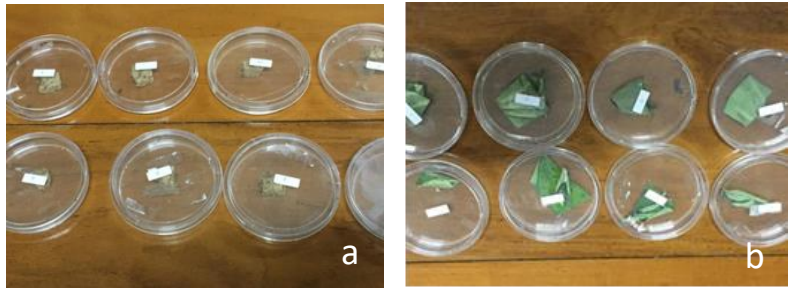

Figure 4 Parasitization of larvae Spodoptera litura which reared in artificial diet (a) and natural diet (b)

\subsection{Our Contribution}

This paper presents the stages of making artificial diet for $S$. litura and result of parasitization rate and sex ratio of parasitoid $M$. manilae. The information which obtained from this research can be a reference for education related to parasitoid and other research. The use of artificial diets on parasitoid rearing can help reduce the time to find the host leave of the larvae which reared.

\subsection{Paper Structure}

This paper is contained of some sections. First section introduces the biology of pest $S$. litura. Second section describe the various control of the pest, including the use of parasitoid. Third section or method section explain the activity of rearing, from the larvae collecting activity until parasitization. In the rearing activity, author used the host leaves (taro leaves as native host), and artificial diet. Parasitization activity showed in the next section to get the number of parasitization rate and sex ratio of parasitoid. Last section explain the research result and the suggestion to next research.

\section{RESULTS AND DISCUSSION}

\subsection{Parasitisation}

Result showed that the average value of the highest parasitized larvae was observed in larvae fed with artificial diet with an average value of 8.6, while at the larvae reared with natural diet was smaller with 8.3 (Figure 5).The difference in the number of parasitic larvae can be influenced by the nutrient contained in the host larvae food. Sumarmi et al. [13], states that the nutritional content of host larvae can affect the endurance, longevity or development of larvae. The ability to survive physically during the pre-parasitization process is also influenced by larval feed content $[3,14,15]$.

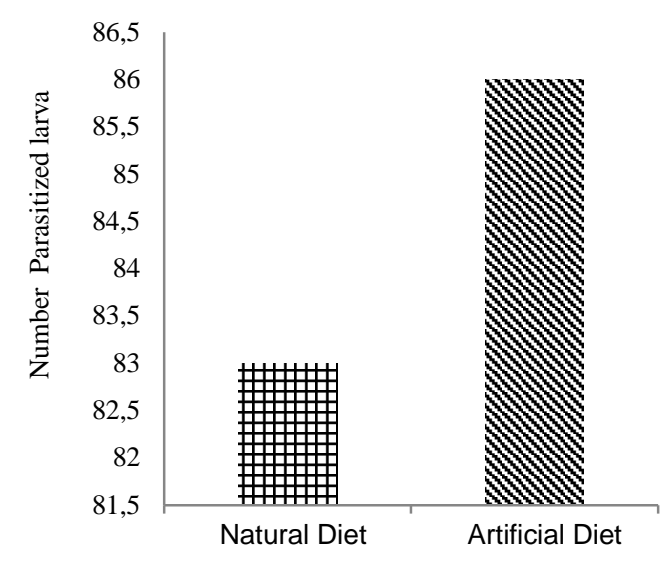

Figure 5 Number larva parasitized, which reared used natural diet (Taro leaves) and artificial diets

\subsection{The Number and Sex Ratio of Parasitoids}

The number of parasitoids emerged from larvae fed by natural diet was higher than the number of parasitoids emerged from larvae fed artificial diet (Figure 6). The difference in the number of emerged parasitoids was might possibly cause by several factors including the existence of host immune system to suppress the parasitoid parasitization process by doing the encapsulation process which is one of the defense systems of larvae that attacked by parasitoids. Gupta et al. [16] and Sumarmi et al. [13] states that the nutrient content found in host larvae can affect the body's resistance, development, life span of $S$. litura larvae. In addition, technical maintenance factors also become one of the obstacles that affects the low parasitoids that arise from larvae that are kept using artificial diet. In this study, it was also found that the mortality rate of host larvae occurred due to the lack of space of the larvae of the host, during the process of eating artificial diet (Table 1). Wet feed conditions caused the mortality of host larvae due to pathogen infection. Ahmad et al. [17] states that extrinsic factors originating from the surrounding environment including the rearing methods can affect the success of insect larvae maintenance by using artificial diet.

The sex ratio obsered of individual parasitoids showed that there were more females than male (Figure 7). This was observed in both host larvae maintenance fed with artificial diet and natural diet. Determination of sex ratio by parasitoids is closely related to the condition of food availability for parasitoids. Female parasitoids will lay eggs if the availability of food or offspring is considered abundant [18]. The strategy in determining sex of parasitoid offspring is one off the main factors in maintaining the continuity of parasitoid species in nature. 
Table 1 Number of larva prapupae mortality

\begin{tabular}{|c|c|c|}
\hline \multirow{2}{*}{ Replicate } & \multicolumn{2}{|c|}{ Mortality prapupae } \\
\cline { 2 - 3 } & Artificial diet & $\begin{array}{c}\text { Natural diet (Taro } \\
\text { Leaves) }\end{array}$ \\
\hline a & 2 & 1 \\
\hline b & 5 & 0 \\
\hline c & 3 & 0 \\
\hline d & 6 & 0 \\
\hline e & 1 & 2 \\
\hline f & 5 & 0 \\
\hline g & 2 & 0 \\
\hline h & 2 & 2 \\
\hline i & 0 & 0 \\
\hline j & 3 & 0 \\
\hline Total & $\mathbf{2 9}$ & $\mathbf{5}$ \\
\hline
\end{tabular}

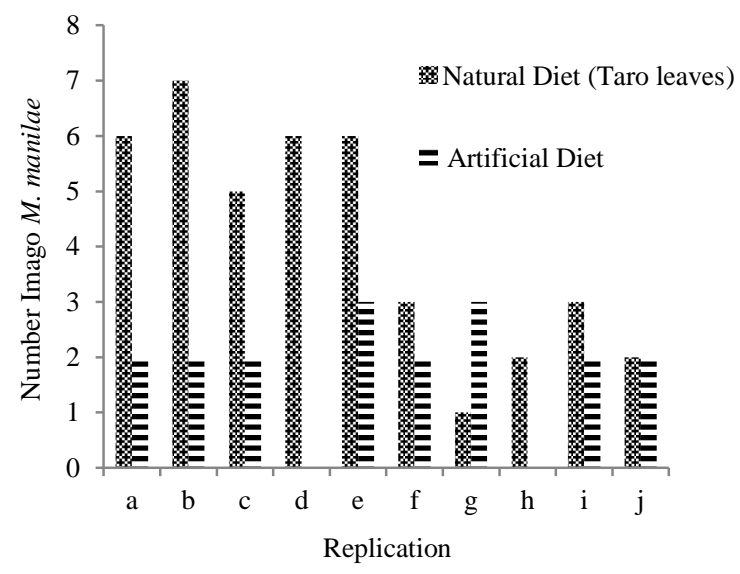

Figure 6 Number of M. manilae emerged from larva reared in natural diet (Taro leaves) and artificial DIET

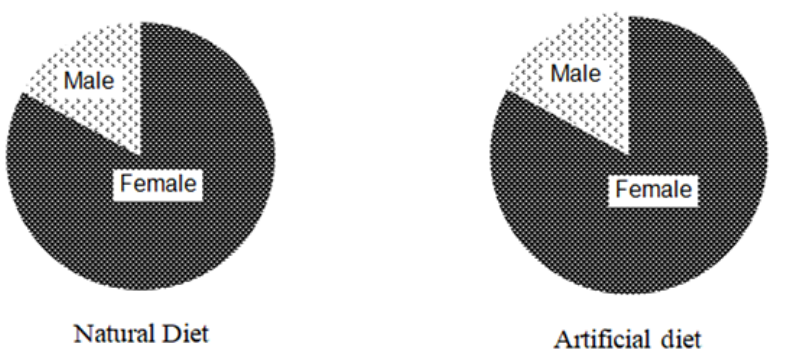

Figure 7 Sex ratio female and male of imago M. manilae

\section{CONCLUSION}

Nutrient content in artificial diet is a major factor that influenced the process of parasitization, the success of parasitization, and the sex ratio of parasitoids. Further studies related to technical maintenance of parasitoids can be support the improvement of the standard methods preparation of parasitoid maintenance by using artificial diet.

\section{ACKNOWLEDGMENT}

The author would like to thank the Director of Human Resources of IPB for provided Research funding (through competitive research grant funding for the IPB Education Laboratory) and also gratitude to the head of the Biological Control Laboratory of the Plant Protection Department of the Faculty of Agriculture, IPB for the laboratory facilities and equipment provision in the implementation of this research.

\section{REFERENCES}

[1] L.G.E. Kalshoven, Pests of Crops in Indonesia. Revised and Translated by PA van der Laan, PT Ichtiar Baru van Hoeve, 1981

[2] K.R. Norris, D.F. Waterhouse, Biological Control Pasific Prospect. Australian Control for International Agricultural Research, Melbourne, Incata Press, 1987

[3] B. Qiu, Z. Zhou, Z. Xu, Age Preference and Fitness of Microplitis manilae (Hymenoptera: Braconidae) Reared on Spodoptera exigua (Lepidoptera: Noctuidae), Fla Entomol. 96 (2), 2013, DOI:https://doi.org/10.1653/024.096.0227

[4] D. Kurniawati, Kesesuaian Instar Larva Spodoptera litura Fabricius (Lepidoptera: Noctuidae) sebagai Inang Parasitoid Larva Snellenius (=Microplitis) manilae Ashmead (Hymenoptera: Braconidae), Sarjana Skripsi, Institut Pertanian Bogor, Bogor, 1998

[5] K. Luo, J.T. Trumble, Y. Pang, Development of Microplitis bicoloratus on Spodoptera litura and Implications for Biological Control, Bio.Control 52 (3) (2006) 309- 321. DOI: https://doi.org/10.1007/s10526-006-9030-8

[6] M.E. Akbar, Pengaruh Lama Ketiadaan Inang Spodoptera litura F. (Lepidoptera: Noctuidae) terhadap Pola Reproduksi Parasitoid Snellenius manilae Ashmead (Hymenoptera: Braconidae), Sarjana Skripsi, Institut Pertanian Bogor, Bogor, 2012

[7] N. Nelly, Yunisman, Y. Rahmawati, Pengaruh Instar Larva Inang Spodptera litura Fabricius (Lepidoptera: Noctuidae) terhadap Keberhasilan Hidup Parasitoid Eriborus argenteopilosus Cameron (Hymenoptera: Ichneumonidae), JEI. 8 (1) (2011) 36-44 
[8] U. Tarwotjo, Beberapa Aspek Biologi Parasitoid Apantheles sp pada Inangnya, Spodoptera litura, Fab. Setelah Perlakuan Ekstrak Daun dan Ranting Aglaia odorata (lour), BIOMA 17 (2) (2015) 68-73. DOI: https://doi.org/10.14710/bioma.17.2.68-73

[9] E. Belz, C.E. Geneau, M. Fuerst, O Balmer, Rearing of Microplitis mediator (Hymenoptera: Braconidae) and its host Mamestra brassicae (Lepidoptera: Noctuidae), European J Entomol. 111 (3) (2004) 443447. DOI: https://doi.org/10.14411/eje.2014.043

[10] M.D. Pathak, Insect Pests of Rice, The International Research Institute, Manila, 1977

[11] L.M. Schoonhoven, J.J.A. van Loon, M. Dicke, Insect-Plant Biolog, Oxford University Press, 2005

[12] E.S. Ratna, Efisiensi Parasitisasi Inang Spodoptera litura (F.) oleh Endoparasitoid Snellenius manilae Ashmead di Laboratorium, J. HPT Trop. 8 (1) (2008) 8-16

[13] S. Sumarmi, T. Nuringtyas, Kartini, Rearing of Croccidolomia binotalis (Zeller) (Lepidoptera: Pyralidae) on the Artifical Diet, Proceedings of $16^{\text {th }}$ IASTEM International Conference, Bali, Indonesia, 2016

[14] J. Li, T.A. Coudron, W. Pan, X. Liu, Z. Lu, Q. Zhang, Host age preference of Microplitis mediator (Hymenoptera:Braconidae), an endoparasitoid of Mythimna separata (Lepidoptera : Noctuidae), Bio $\begin{array}{llll}\text { Control } & 39 & \text { (2006) } & \text { 257-261 }\end{array}$ DOI:https://doi.org/10.1016/j.biocontrol.2006.09.002

[15] P. Sreelakshmi, T.J. Matthew, Development of castor based oligidic diet for tobacco caterpillar, Spodoptera litura (Fabricius) and its comparative study with other artificial and natural diets, J. Entomol. Zool. Stud. 5 (3) (2017) 1040-1044

[16] G.P. Gupta, S. Rani, A. Birah, \& M. Raghuraman, Improved artificial diet for mass rearing of the tobacco caterpillar, Spodoptera litura (Lepidoptera: Noctuidae), Int J. Trop. Insect. Sci. 25 (1) (2005) 5556 DOI: https://doi.org/10.1079/IT200551

[17] I.M. Ahmad, A defined artificial diet for the larvae of Manduca sexta, Entomol. Exp. Appl.53 (1989)189191

[18] A.L.Joyce, J.G. Millar, T.D. Paine, L.M Hanks, The effect of host size on the sex ratio of Syngaster lepidus, a parasitoid of eucalyptus longhorned borers (Phoracantha spp.), Bio Control 24 (2002) 207-213. DOI: https://doi.org/_10.1016/S1049-9644(02)000312 